\title{
The Development of Karo Souvenir Design Inspired by Padung-padung
}

\author{
Ariani Rachman \\ Product Design Department, Faculty of Art and Design \\ Trisakti University Jakarta, Indonesia \\ arravqa@gmail.com
}

\begin{abstract}
Tanah Karo is one of the areas in North Sumatra that has a variety of tourist destinations because of its cultural richness and natural beauty. To support the government's program in realizing Tanah Karo as one of tourist destination that is cultured and competitive, one effort that can be done to support the goal is to provide souvenirs that reflect the local wisdom of Tanah Karo. Padung-padung, a unique earring with admirably large size that contains philosophy meaning of Karo tribe, can be applied in the development of souvenir design as a media between art and culture of past with society today. This research aims to develop souvenir designs inspired by padungpadung. Qualitative research will be conducted to describe the analyze result, accompanied by tourism theories and research and development approach.
\end{abstract}

Keywords: padung-padung, souvenir design, Karo tourism

\section{INTRODUCTION}

Padung-padung is a type of gold and silver earrings with a fairly large size and weighed around $1.5-2 \mathrm{~kg}$, which is worn by inserting it into the hole in the earlobe and attach the other end to the cloth covering the head. Karo women wore the jewelry in the past as accessories and also as a status symbol. In addition to being unique and beautiful, like other ornaments from local culture in Indonesia, padungpadung is full of philosophical meanings that enrich the customs and traditions of Karo tribe. Nowadays, padungpadung is no longer used, and many Karo people especially the young generation do not realize its existence. This is of course very unfortunate, considering if this continues, it will certainly an impact on the connection between the origins of our ancestors in the past to the present. Therefore, the revitalization of padung-padung in the case of local wisdom is needed, both in the physical form and philosophical meaning. There are two main reasons behind the revitalization of padung-padung, namely the revitalization will reinforce the identity of Karo tribe in a small scope and Indonesian identity as a nation with a rich and diverse culture, and also as an effort to pass on the local wisdom toward the future generation to recognize and love own culture.

Revitalization efforts can be done by using an intermediary media in the form of products or works to connect padung-padung with the community. One of the media or objects can be used is souvenir. In the 2013-2018 Department of Culture and Tourism of North Sumatera Province Strategic Plan is stated that in the implementation, the development of culture and tourism of North Sumatera has a weakness, one of which is the deficiency of processed products and souvenirs. For people who have visited Karo and other North Sumatera regions, souvenirs play a memorable role after visiting certain locations, including everything seen there. Souvenirs can also function as a means to deliver the message of padung-padung existence in the past to people. Even without the story from the person who brings it, the visualization of the souvenir should also be attractive to the person who will observe it. Therefore, a design needs to reflect the local wisdom of padung-padung in a more contemporary form to align with the modern times.

\section{LITERATURE REVIEW}

Padung-padung is a unique jewelry due to its unusual size and weight compared to earrings in general. How to wear it is also unique because it has to be attached to the cloth covering the head in order to reduce the weight that must be borne by the wearer's head. The simple shape of padung-padung turns out to have a deep philosophical meaning on Karo culture in the past, namely the close relationship between the people and nature, the love of a father to his daughter, and a wisdom in facing life challenges. In the contemporary life, the traditional way of living shifts to a more modern style. Post-war modernization slowly shifted the local culture, which was previously very solid, and one of it is the use of padungpadung. Padungpadung that once was part of the daily jewelry worn by Karo women has begun to be abandoned on the grounds of practicality. One way we can do to preserve its sustainability is to explore the potential of the jewelry and apply it in various products tailored to the needs of the society in this contemporary era. With various adjustments, for example in size, use of materials, functions, and other factors, padungpadung can be an interesting alternative aesthetic element to develop. Some examples of products that apply padungpadung as an aesthetic element are jewelry and souvenir designs [1].

Souvenir is related closely to a person's "travel" activity thus it is not surprising when the term souvenir is attached to tourism activities; even becomes a part of tourism products. In addition to tourism sites, souvenir is one of the attractions for tourists, especially those with local orientation, where tourists always want to bring home a memorable item produced by the local community where they visit. This is in line with the 3 principles of tourism attractions, namely: 1) Something to see, 2) Something to do, 3) Something to buy [2]. Therefore, the right souvenirs to be produced in the tourism site are souvenirs that represent the characteristics of the area. Tourism souvenir products are products that are produced and consumed in relation to tourism. The characteristics of tourism souvenirs are (1) imitation of the original, (2) short, solid, or miniature of the original, (3) full of 
variety, (4) left out the sacred, magic, and symbolic value, and (5) affordable price [3]. This product is deeper in understanding compared to the souvenir limited in the criteria of small, light and cheap, but also related to social and cultural values representing the characteristics of a certain region. The existence of tourism souvenirs certainly cannot be separated from their function and meaning. The functions include supporting the tourism site existence, where tourism object offers beauty, joy, and happiness psychologically, while the souvenirs offer something to be physically owned. Tourism souvenirs are objects for a person to connect inward (memories, visualization, imagination) regarding the place he once visited [4]. The product is broadly meaningful, for as the support of tourism, it is expected to shape the good image of the tourism site. The meaning is the representation of natural environment characteristics and socio-cultural life of the local community. Souvenirs as part of tourism serve to keep memories, as a symbol that someone has made a tourism visit. Furthermore, souvenirs are able to awaken a person's memory to revisit a certain tourism site [5].

\section{PROBLEM STATEMENTS}

The result of data analysis in the field generates a conclusion that the available souvenirs in several tourism objects in Karo Regency and other locations have not fully represented the characteristics of the region. Therefore, the focus of discussion in this research is how to apply the form of padung-padung as an inspiration for the development of tourism souvenirs design of Karo, North Sumatera, which follows the modern development but still reflects the identity and local wisdom of Karo tribe.

\section{METHODOLOGY}

Literature studies and interview methods are conducted to acquire accurate data and information. After the data is collected, analysis will be done using qualitative methodology to describe the result of analysis. The methodology used is Research and Development (R\&D). The Research and Development methodology, which will later abbreviate into $R \& D$, is a research methodology used to produce a certain product, and examine the effectiveness of the product [6]. With this method, the researcher carries out a series of steps, namely preliminary study (literature and field study), planning (implementation of padungpadung shape into souvenirs design), application (modeling, molding, casting, production), souvenir quality testing and evaluating, until producing souvenir design inspired by padung-padung.

\section{RESULTS AND ANALYSIS}

Based on the result of analysis, it is known that in a simple form that carries a deep meaning, padung-padung form can be applied as the basis for souvenir design creation that reflect the identity and local wisdom of Karo tribe, yet still consider the current trend. This is important in the effort to participate in preserving and raising the characteristics of local cultural arts to be known at national and international levels. In addition, the products result from the research can also be used as special souvenirs of Karo, North Sumatera, thus can indirectly help to enliven and enhance the tourism industry, especially in North Sumatera region.

\section{DISCUSSION}

\section{A. Cultural Tourism Potential in Karo Regency and Available Souvenirs}

North Sumatera Province, especially Karo Regency, has a number of unique tourism attractions, both nature and culture. However, the existing conditions of tourism attractions that stand out today are the nature tourism. In this case, Karo nature tourism often see only physically as 'object', which is separated from its traditional and cultural value. In this research, the discussion on Sumatera tourism will focus on Karo Lands, considering padung-padung is originated from the region. In the Government Work Plan Year 2018, there are three stipulated leading sectors, one of which is tourism sector especially cultural tourism. This will certainly provide new opportunities for local government to develop a culture-based tourism concept in their region. To support the government program, a development in souvenir industry filled with local wisdom of Karo tribe needs be done as part of the effort to optimize the creative industry potential in Karo Lands. In this case, souvenirs play an important role in promoting the existence of padungpadung that is rich with Karo cultural values through the intermediaries of tourist.

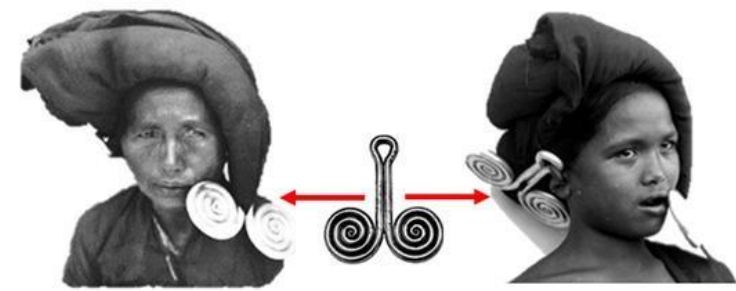

Figure. 1. Padung-padung and how to wear it

Tourism souvenirs in Karo Lands region are mostly based on the cultural characteristics of North Sumatera, especially Batak, such as batak statue, batak calendar, Bolon miniature, and many more. There are not many souvenirs based on Karo culture. Some products are even irrelevant and do not portray Karo cultural characteristics, but are marketed as souvenirs in Karo Lands, for example batiktype products, Javanese mask, and ceramic products imported from Java and Bali. Based on the result analysis of Karo cultural tourism character, the alternative of souvenir development by utilizing padung-padung potential that is unique and filled with philosophical meaning is worth developing. The souvenir forms can range from decorative products, a simplification of padung-padung form, and daily functional products (applied art).

\section{B. The Development of Karo Souvenir Design Inspired}

by Padung-padung

To qualify as souvenirs, padung-padung is made as its original form, the size is adjusted to its function, abandoning its sacred value, but retain its intangible value, made in several variations, with affordable price for tourists. The alternative souvenir designs made by applying padungpadung in it, both in terms of shape and visual elements. The following are several design 
alternatives for souvenirs made by applying research and development method (R\&D):

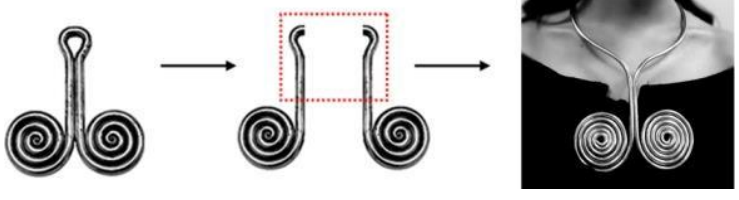

Figure. 2. Process of applying padung-padung shape into choker design

In the choker design above, the material used is sterling silver, silvadium, or argentium. Sterling silver is the most common material used for crafts and jewelry. In Indonesia, this type of silver is known as silver 925. Sterling silver is light and easy to shape. Silver material is chosen for this design for its convenience in the process/shaping as well as its flexible, modern, and luxurious appearance. The end of the choker is shaped like padung-padung.

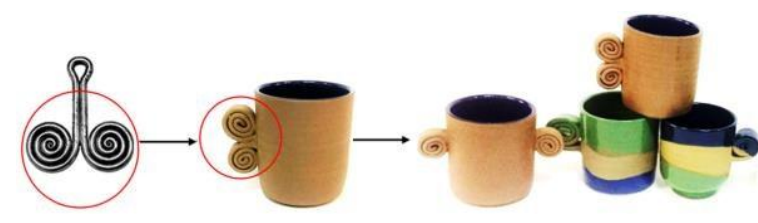

Figure. 3. A souvenir design of cups

Souvenirs in the form of drinking cups are made of ceramic (stoneware) with the characteristic of the handle that is adapted from shape development of padung-padung. The glazes used are natural colors, namely blue, green, and earth color on the outer and inner surface to reflect the close relationship between Karo people and nature. The application of padungpadung shape in cup handle is based on the daily needs of people to drink, thus daily interaction with the device will make the memory of padung-padung to always remain.
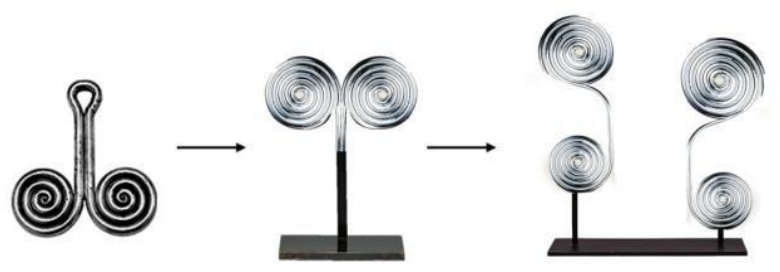

Figure. 4. A souvenir design of decoration

The decoration takes the spiral form of padungpadung. The spiral has variety of meanings. When summarized, the symbolic meaning of spiral is to describe the power of the sun and the moon, air, water, thunder and lightning, vortex, and creative potential. In contrast, spiral also portrays the rise and fall of the sun, the ups and downs of the moon, growth-development-death, depreciation, entanglement and openings, birth and death (Cooper, 1987). A father gives padung-padung to his daughter on her wedding day as a symbol of a new status after marriage (Brinkgreve \& StuartFox, 2013). Hence, being deeply examined, the meaning behind the provision of padung-padung is the father indirectly wants to convey a message to the daughter to be wise in addressing challenges that will arise in marriage life. The decoration is made from wrought iron shaped with bending technique and finished in chrome coating.

Some of the examples of souvenirs above are made by applying research and development (R\&D) methodology, which means that it has gone through numerous processes before generating fixed designs. The designs can still be further developed, tailored to the modern development. The souvenir designs are expected to reflect the identity and local wisdom of Karo tribe, yet still considering the current factors.

\section{CONCLUSION}

Based on the discussion above, it can be concluded that the potential of souvenir development by applying the form of padung-padung is highly possible considering its simple but characterized form. In the process, there are design principles that must be followed, namely design application principles (balance, contrast, rhythm, emphasis, proportion, unity, movement) and design elements (line, form, shape, color, space, value, texture). With various adjustments for example in term of size, use of materials, function, and other factors, padung-padung can be an interesting source of inspiration to develop. This function transformation process has occurred in numerous artifacts in Indonesia as an effort to preserve its sustainability but in the form that adapts to current conditions.

\section{ACKNOWLEDGMENT}

This research project would not have been possible without support by Dr. Ganal Rudiyanto, M.Hum as Dean of Faculty of Art and Design, Trisakti University that enabled the author to present this paper at the 3rd International Conference on Creative Media, Design \& Technology (REKA2018), under the title, "The Development of Karo Souvenir Design Inspired by Padung-Padung".

\section{REFERENCES}

[1] Ariani. 2017. Reviving Padung-Padung to Preserve Karo Tribe Cultural Identity. International Journal of Culture and History, Vol. 3, No. 2, pp 116-120, June 2017.

[2] Yoeti, O. A. 1996. Pengantar Ilmu Pariwisata. Bandung: Penerbit Angkasa.

[3] Soedarsono, R.M. 1999. Metodologi Penelitian Seni Pertunjukan dan Seni Rupa. Bandung: Masyarakat Seni Pertunjukan.

[4] Causey, Andrew. 2006. Danau Toba: Pertemuan Wisatawan dengan Batak Toba di Pasar Souvenir. Medan: Bina Media Perintis.

[5] Atmojo, Wahyu Tri. 2007. Dampak Pariwisata terhadap Perkembangan Seni Kerajinan Kayu di Gianyer Bali 1930-2002: Kelangsungan dan Perubahannya. Disertasi Sekolah Pascasarjana Universitas Gajah Mada Yogyakarta.

[6] Sugiyono. 2006. Metode Penelitian Kuantitatif Kualitatif dan R\&D. Bandung: Penerbit Alfabeta

[7] Cooper, J.C. 1987. Encyclopedia of Traditional Symbols. London: Thames and Hudson

[8] Brinkgreve, F., \& D.J. Stuart-Fox (eds). 2013. Living with Indonesian Art: The Frits Liefkes Collection. Rijksmuseum Volkenkunde 